\title{
Hyponatremia prolongs hospital stay and hypernatremia better predicts mortality than hyponatremia in hospitalized patients with community-acquired pneumonia
}

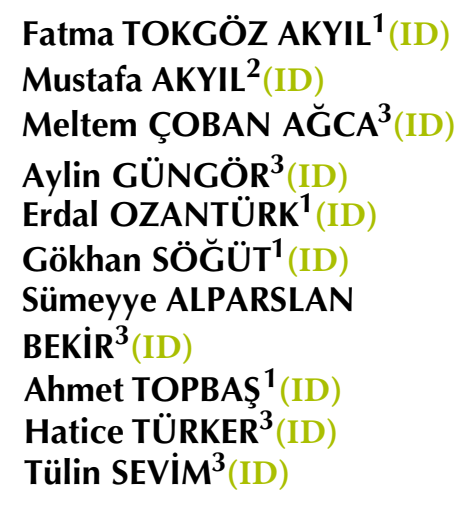

Fatma TOKGÖZ AKYIL Mustafa AKYIL ${ }^{2}$ (ID) Meltem CCOBAN AGCA Aylin GÜNGÖR ${ }^{3}$ (ID)! Erdal OZANTÜRK Gökhan SÖĞÜT'1 ${ }^{1}$ Sümeyye ALPARSL̄ĀÑ BEKIR $^{3}$ (ID) Ahmet TOPBAS ${ }^{1}$ (ID) Hatice TÜRKER ${ }^{3}(\mathrm{ID})$ Tülin SEVIM ${ }^{3}$

Cite this article as: Tokgöz Akyıl F, Akyıl M, Coban Ağca $M$, Güngör A, Ozantürk E, Sögüt G, et al. Hyponatremia prolongs hospital stay and hypernatremia better predicts mortality than hyponatremia in hospitalized patients with community-acquired pneumonia. Tuberk Toraks 2019;67(4):239-47.

\section{Yazışma Adresi (Address for Correspondence)}

\section{Dr. Fatma TOKGÖZ AKYIL}

Canakkale Mehmet Akif Ersoy Devlet Hastanesi, Göğüs Hastalıkları Kliniği,

Kepez, ÇANAKKALE - TÜRKIYE

e-mail: fatmatokgoz86@gmail.com

CCopyright 2019 by Tuberculosis and Thorax.

Available on-line at www.tuberktoraks.org.com
${ }^{1}$ Clinic of Chest Diseases, Canakkale Mehmet Akif Ersoy State Hospital, Canakkale, Turkey

${ }^{1}$ Çanakkale Mehmet Akif Ersoy Devlet Hastanesi, Göğüs Hastalıkları Kliniği, Çanakkale, Türkiye

${ }^{2}$ Clinic of Chest Surgery, Canakkale Mehmet Akif Ersoy State Hospital, Canakkale, Turkey

${ }^{2}$ Çanakkale Mehmet Akif Ersoy Devlet Hastanesi, Göğüs Cerrahisi Kliniği Çanakkale, Türkiye

${ }^{3}$ Clinic of Chest Diseases, Istanbul Sureyyapasa Chest Diseases and Chest Surgery Training and Research Hospital, Istanbul, Turkey

3 istanbul Süreyyapaşa Gögüs Hastalıkları ve Gögüus Cerrahisi Ĕgitim ve Araştırma Hastanesi, Göğüs Hastalıkları Kliniği, Istanbul, Türkiye

\begin{abstract}
Hyponatremia prolongs hospital stay and hypernatremia better predicts mortality than hyponatremia in hospitalized patients with communityacquired pneumonia
\end{abstract}

Introduction: Dysnatremia is reported to have a prognostic effect in various diseases. A limited number of studies have been published on dysnatremiarelated parameters and clinical outcome in patients with pneumonia. The aim of the study is to analyze the factors related to baseline dysnatremia and to evaluate the clinical outcome of dysnatremia on hospital stay, 30-day and 1-year mortality in hospitalized patients with community-acquired pneumonia $(C A P)$.

Materials and Methods: The study is a two-centre, retrospective, crosssectional study. According to the baseline corrected sodium values, hospitalized patients with CAP were grouped as hyponatremia $<135$ $\mathrm{mmol} / \mathrm{L}$ ), normonatremia $(135-145 \mathrm{mmol} / \mathrm{L}$ ) and hypernatremia (> 145 $\mathrm{mmol} / \mathrm{L}$ )

Results: Of all the 471 patients included, 119 (25.3\%) had hyponatremia and $25(5.3 \%)$ had hypernatremia. Higher leucocytes and lower albumin values correlated with hyponatremia while female gender, higher leucocytes and urea levels correlated with hypernatremia. Baseline hyponatremia prolonged hospital stay $(9.2 \pm 5.6, v s .7 .5 \pm 4.6$, respectively, $p=0.001)$ and increased 1-year mortality. On the other hand, hypernatremia predicted 30 -day $(40 \%$, vs. $10 \%, p<0.001)$ and independently predicted 1-year mortality $(p<0.001)$. 
Conclusion: In hospitalized patients with CAP, baseline hyponatremia prolongs hospital stay while hypernatremia signals a worse outcome both in the short term and long term.

Key words: Charlson comorbidity index; glucose; hyponatremia; hypernatremia

\section{Öz}

Hastanede tedavi edilen toplumda gelişen pnömonide hiponatremi hastane yatışını uzatır ve hipernatremi mortalite için hiponatremiden daha güçlü bir belirteçtir

Giriş: Disnatreminin birçok hastalıkta prognostik etkisi olduğu gösterilmiştir. Pnömoni hastalarında disnatremi ile ilişkili faktörler ve klinik önemi ile ilişkili az sayıda çalışma yayınlanmıştır. Bu çalışmanın amacı hastanede tedavi edilen toplumda gelişen pnömoni (TGP) hastalarında disnatremi ile ilişkili faktörleri belirlemek, disnatreminin hastane yatış süresi, kısa ve uzun dönem mortalite ile ilişkisini araştırmaktır.

Materyal ve Metod: Çalışma iki merkezli, retrospektif bir çalışmadır. TGP tanısı ile hastanede tedavi başlanan hastalar bazal sodyum değerlerine göre hiponatremi (< $135 \mathrm{mmol} / \mathrm{L})$, normonatremi (135-145 mmol/L) ve hipernatremi (> $145 \mathrm{mmol} / \mathrm{L}$ ) olarak gruplandlrıldı.

Bulgular: Çalışmaya dahil edilen 471 hastanın 119 (\%25.3)'unda hiponatremi, 25 (\%5.3)'inde hipernatremi tespit edildi. Hiponatremi ile yüksek lökosit ve düşük albumin değerlerinin; hipernatremi ile kadın cinsiyet, yüksek lökosit ve üre değerlerinin ilişkili olduğu bulundu. Bazal hiponatreminin hastane yatış süresini uzattığı (9.2 \pm 5.6 gün ve $7.5 \pm 4.6$ gün; sırasıyla, p=0.001) saptandı. Hipernatreminin bir aylık mortalite riskini artırdı̆̆ı (\%10 vs. \%40, p<0.001) ve bir yıllık mortalite için bağımısz risk faktörü olduğu belirlendi $(p<0.001)$.

Sonuç: Hastanede tedavi edilen TGP hastalarında bazal hiponatremi hastane yatışını uzatan hipernatremi hem kısa hem uzun dönem mortaliteyi artıran belirteçlerdir.

Anahtar kelimeler: Charlson komorbidite indeksi; glukoz; hiponatremi; hipernatremi

\section{INTRODUCTION}

Community-acquired pneumonia (CAP) is a common serious health-problem, being the second most common cause of hospitalization and the most common infectious etiology of mortality worldwide $(1,2)$.

Presence of dysnatremia is described as a determiner of mortality in various studies $(3,4)$. Sodium is the main factor to determine plasma osmolality and sodium disturbance is among the most common laboratory abnormalities in clinical practice (5). The kidney and thirst center of the hypothalamus play the major role in sodium regulation. Skin and other tissues may accumulate sodium. Sodium disturbance may be caused by advanced age, drugs, comorbidities and hydration status (4). Hypernatremia is mainly developed by decreased total body water through insensible losses and sepsis. In hypernatremia, plasma osmolality increases mediating with water efflux and cell shrinkage. Import of the ions trigger organic osmolyte accumulation and due to intracellular molecular crowding, cellular reactive oxygen species and cytokines; cell damage continues (6). Hyponatremia may be seen in malignancies, infections or as a drug side effect. It results mainly from non-osmotic vasopressin activity (7). Hyponatremia and hypernatremia may result with altered mental status and coma (8).
In current guidelines of CAP, hyponatremia is one of the criteria in pneumonia severity index whereas hypernatremia is not specified (9). Only few studies have analyzed the predictive factors for dysnatremia in patients with CAP. Older age, higher Charlson comorbidity index $(\mathrm{CCl})$ scores, baseline leucocytes and C-reactive protein (CRP) levels were described as predictors of hyponatremia (10-12). Fewer studies have focused on hypernatremia-related parameters regarding the patients treated in nonspecific units and septic intensive care unit (ICU). Advanced age, co-morbidities, lower estimated glomerular filtration rate and acute physiology and chronic health evaluation II scores are claimed to increase the risk of hypernatremia $(4,13,14)$.

Short-term mortality is reported higher in patients with hyponatremia in a number of studies with different study designs $(3,15-19)$. The presence of a U-shaped association between the degree of hyponatremia and mortality risk is a controversial issue $(15,16,18)$. In contrast with these studies, in-hospital mortality was reported not to be related to hyponatremia in another study (11).

Hypernatremia is a rare laboratory abnormality and if present, it increases mortality in overall hospital admissions (13,14,20-22). A limited number of studies including CAP patients have also described higher 
mortality in hypernatremia (12). The literature demonstrates a scarcity of search results on the predictive analysis of dysnatremia regarding the long-term outcome of CAP patients (12).

In present study, correlative factors for baseline dysnatremia in hospitalised patients with CAP were investigated. The predictive value of both hyponatremia and hypernatremia for the length of hospital stay (LOS) and both short- and long-term mortality were analyzed.

\section{MATERIALS and METHODS}

The present study is a two-centre, retrospective, designed in a chest diseases clinic at a state hospital (Center 1) and a training and research hospital (Center 2).

This study is derived from two centers in two discrete cities. In the city of the first center, there are two spe- cialized clinics and our study includes the larger of these (the center with the 30-bed capacity). The city of the second center is a very populous city and the study includes mainly a sublinic (with a 34-bed capacity) of a large center.

\section{Inclusion of the Patients}

A hospital database system search was conducted via International Classification of Diseases, $10^{\text {th }}$ version codes of $\mathrm{J18}$ (pneumonia) among hospitalized patients between January 2017 and January 2018. All patients' clinical files were investigated to verify a diagnosis of CAP. Hospital-acquired pneumonia, ICU-transferred patients, patients without recorded baseline sodium levels were excluded (Figure 1).

The study was performed in accordance with relevant ethical principles of Helsinki Declaration and

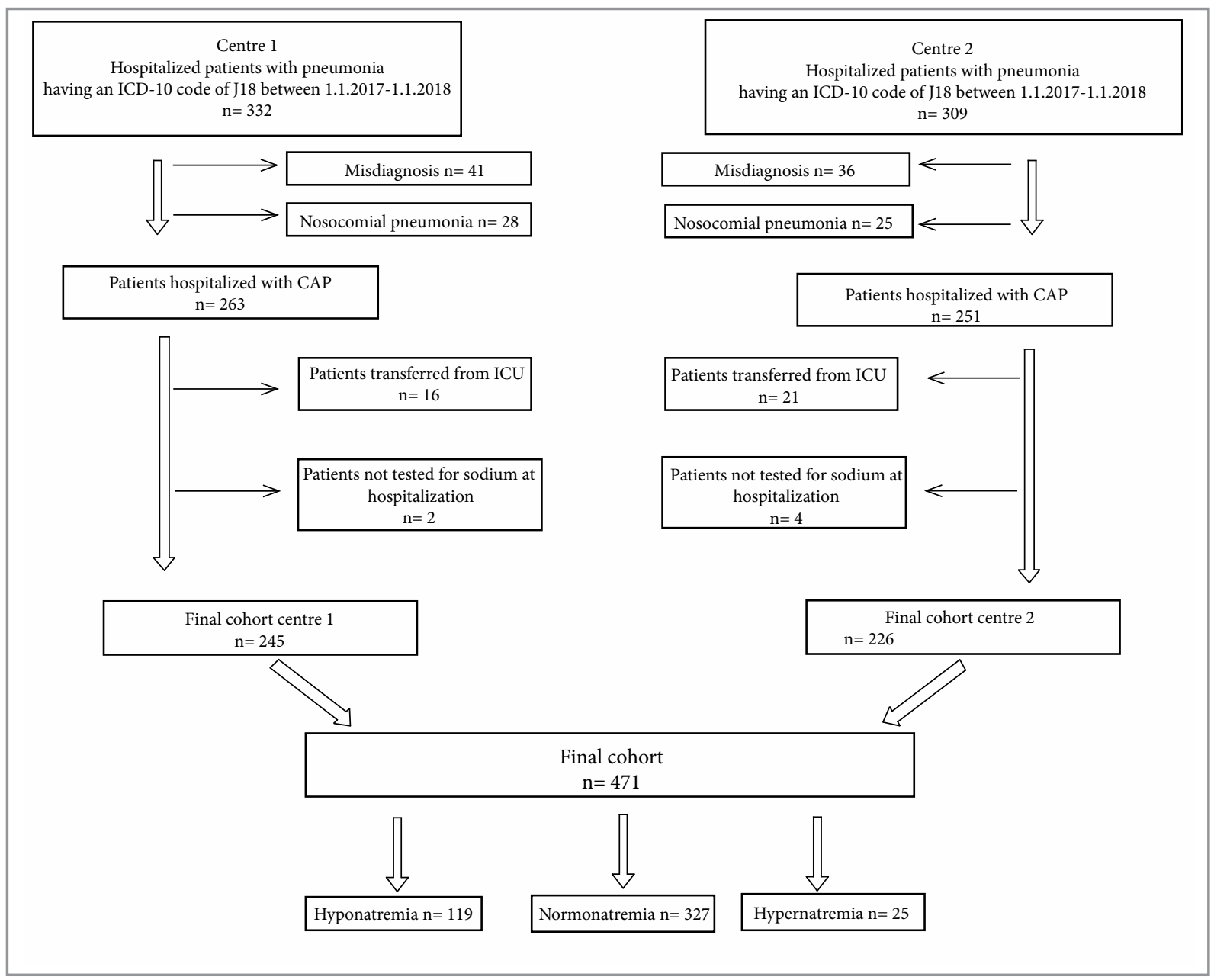

Figure 1. Flowchart of the patient inclusion.

CAP: Community-acquired pneumonia, ICD: International classification of diseases, ICU: Intensive care unit. 
approved by the ethics committee of Canakkale Onsekiz Mart University (2011-KAEK-27/20191900067286). Written informed consent was not obtained from the patients due to the retrospective design of the study.

\section{Definitions}

CAP: Compatible symptoms (cough, sputum, shortness of breath), physical examination findings and imaging findings on chest X-ray or thorax computerized tomography (CT) (9).

Dysnatremia: Serum sodium levels out of range 135$145 \mathrm{mmol} / \mathrm{L}$. Hyponatremia: a baseline serum sodium concentration of $<135 \mathrm{mmol} / \mathrm{L}$, severe hyponatremia: a baseline serum sodium concentration of < $130 \mathrm{mmol} / \mathrm{L}$. Hypernatremia: a baseline serum sodium level of $>145 \mathrm{mmol} / \mathrm{L}(23)$.

\section{Data Collection}

Age, gender, complaints (shortness of breath, cough, sputum, fever, chest pain, hemoptysis), co-morbid diseases, baseline complete blood count parameters of leucocytes $(/ \mu \mathrm{L})$, hemoglobin $(\mathrm{g} / \mathrm{dL})$, platelet $(/ \mu \mathrm{L})$, neutrophils $(/ \mu \mathrm{L})$ and lymphocytes $(/ \mu \mathrm{L}), \mathrm{CRP}(\mathrm{mg} / \mathrm{L})$, glucose $(\mathrm{mg} / \mathrm{dL})$, blood urea nitrogen $(B U N)(\mathrm{mg} / \mathrm{dL})$, albumin $(\mathrm{g} / \mathrm{dL})$ and sodium $(\mathrm{mEq} / \mathrm{L})$ levels were recorded. To correct sodium levels, each $100 \mathrm{mg} / \mathrm{dL}$ increment in glucose levels higher than $100 \mathrm{mg} / \mathrm{dL}$, sodium levels were adjusted upward by $2 \mathrm{mEq} / \mathrm{L}$ (13). Neutrophils to lymphocytes ratio (NLR) and CCI scores were calculated (24).

\section{Study Design}

Baseline sodium levels were classified as hyponatremia, normonatremia and hypernatremia. Demographics, baseline laboratory values of hyponatremic and normonatremic patients as well as of hypernatremic and normonatremic patients were compared.

Outcome measures were length of hospital stay (LOS), one-month mortality and 1-year mortality according to baseline sodium levels.

Mortality was questionnaired via National Death Database (www.obs.gov.tr).

\section{Statistical Analysis}

All statistical analyses were conducted using a statistical software package (SPSS for Windows, version 16.0; SPSS Inc.; Chicago, IL, USA). Quantitative data are expressed as mean \pm standard deviation $(\mathrm{SD})$ and qualitative data are expressed as frequencies. Independent sample t-test was used for the comparison of averages and chi-square test was used for the categorical variables. Logistic regression test was used for independent predictors of hyponatremia. Cox-regression analysis was used for multivariable analysis of one-year independent predictors of mortality. A $p$ value of $\leq 0.05$ was considered to be significant.

\section{RESULTS}

Of all the 471 patients included, the mean age was $66 \pm 18$ years and $313(67 \%)$ were male. Complaints at presentation were shortness of breath $(n=368$, $78 \%)$, cough $(n=354,75 \%)$, sputum $(n=282,60 \%)$, fever $(n=177,38 \%)$, weakness, $(n=78,17 \%)$ and general condition impairment $(n=21,5 \%)$. The most frequent co-morbidities were chronic obstructive pulmonary disease or asthma $(n=205,44 \%)$, congestive heart failure $(n=79,15 \%)$, diabetes mellitus $(n=$ $94,20 \%)$, malignancy $(n=66,14 \%)$, coronary artery disease $(n=63,13 \%)$, serebrovascular disease $(n=$ $63,14 \%)$, connective tissue disease $(n=9,2 \%)$ and chronic renal failure $(n=30,6 \%)$. The average $\mathrm{CCl}$ score was $3.8 \pm 2.1(0-10)$. Baseline sodium values were classified as normonatremia in 327 (69.4\%), hyponatremia in 119 (25.3\%) and hypernatremia in $25(5.3 \%)$ patients. Thirty-day, 90-day and 1 -year mortality were seen in $56(12 \%), 81(17 \%)$ and 135 (29\%) patients, respectively.

Comparison of hyponatremic and normonatremic patients revealed no difference between gender, age, presentation symptoms, NLR and platelets. Although hyponatremic patients had higher $\mathrm{CCl}$ scores, there was no statistical difference. In hyponatremia, patients had higher levels of leucocytes $(p=0.001)$ and CRP $(p=0.009)$. Albumin levels were significantly lower in hyponatremia $(p<0.001)$ (Table 1). In multivariable analysis, higher leucocytes and lower albumin levels were determined as independent predictors of hyponatremia (Table 2).

In hyponatremic patients, LOS was significantly longer $(p=0.001)$. In-hospital mortality was seen in 13 of hyponatremics $(11 \%)$ and $32(10 \%)$ of normonatremics $(p=0.724)$. In one-year, $42(35 \%)$ of hyponatremics and $78(24 \%)$ of normonatremics died $(p=$ 0.035). Hyponatremia did not alter 30-day mortality while it increased one-year mortality. When levels of sodium were categorized, the lowest death rate was 
Table 1. Comparison of patients with normonatremia and hyponatremia

\begin{tabular}{|c|c|c|c|}
\hline & $\begin{array}{c}\text { Normonatremia } \\
(135-145 \mathrm{mmol} / \mathrm{L}) \\
(\mathrm{n}=327)\end{array}$ & $\begin{array}{c}\text { Hyponatremia } \\
(<135 \mathrm{mmol} / \mathrm{L}) \\
(\mathrm{n}=119)\end{array}$ & $\mathbf{p}$ \\
\hline Male gender, n (\%) & $218(67)$ & $85(71)$ & 0.361 \\
\hline Age, years & $65(19)$ & 67 (19) & 0.367 \\
\hline $\mathrm{CCl}$ score & $3.6 \pm 2.1$ & $4.1 \pm 2.1$ & 0.057 \\
\hline Leucocytes $(/ \mu \mathrm{L})$ & $12.8 \pm 6.5$ & $15.1 \pm 7.9$ & 0.001 \\
\hline Hemoglobin $(\mathrm{g} / \mathrm{dL})$ & $12 \pm 1.9$ & $12 \pm 2$ & 0.966 \\
\hline NLR & $10.8 \pm 21$ & $14 \pm 13$ & 0.157 \\
\hline Platelets $(/ \mu \mathrm{L})$ & $278 \pm 121$ & $281 \pm 145$ & 0.843 \\
\hline CRP (mg/L) & $130 \pm 106$ & $162 \pm 118$ & 0.009 \\
\hline BUN (mg/dL) & $49 \pm 30$ & $54 \pm 34$ & 0.221 \\
\hline Albumin $(\mathrm{g} / \mathrm{dL})$ & $2.3 \pm 1.4$ & $1.8 \pm 1.2$ & $<0.001$ \\
\hline LOS (days) & $7.5 \pm 4.6$ & $9.2 \pm 5.6$ & 0.001 \\
\hline 30-day mortality, n (\%) & $32(10)$ & $13(11)$ & 0.724 \\
\hline 1-year mortality, n (\%) & $78(24)$ & $42(35)$ & 0.035 \\
\hline
\end{tabular}

Table 2. Results of the logistic regression analysis for correlative factors of hyponatremia

\begin{tabular}{|lcccccc|} 
& Beta coefficient & Standard error & Wald & Significance & Exponential beta & $\mathbf{9 5} \% \mathbf{C l}$ \\
\hline Leucocytes $(/ \boldsymbol{\mu L})$ & $\mathbf{0 . 0 4 0}$ & $\mathbf{0 . 0 1 8}$ & $\mathbf{5 . 2 4 8}$ & $\mathbf{0 . 0 2 2}$ & $\mathbf{1 . 0 4 1}$ & $\mathbf{1 . 0 0 6 - 1 . 0 7 7}$ \\
CCl score & 0.069 & 0.058 & 1.430 & 0.232 & 1.071 & $0.957-1.199$ \\
CRP (mg/L) & 0.002 & 0.001 & 2.293 & 0.130 & 1.02 & $0.999-1.004$ \\
Albumin (g/dL) & $\mathbf{- 0 . 3 2 8}$ & $\mathbf{0 . 0 9 4}$ & $\mathbf{1 2 . 0 7 8}$ & $\mathbf{0 . 0 0 1}$ & $\mathbf{0 . 7 2 0}$ & $\mathbf{0 . 5 9 9 - 0 . 8 6 7}$ \\
Constant & -1.399 & 0.401 & 12.177 & 0.000 & 0.247 & \\
\hline CCl: Charlson comorbidity index, CRP: C-reactive protein. & & & & \\
\hline
\end{tabular}

between the values of $135-140 \mathrm{mmol} / \mathrm{L}$. Once the score of $140 \mathrm{mmol} / \mathrm{L}$ was passed, an increasing trend for mortality was observed (Figure 2).

Both hypernatremic and normonatremic patients exposed similar complaints. Hypernatremia was detected more frequently in females $(p=0.009)$ and at advanced age $(p=0.025)$. Hypernatremics had higher baseline leucocytes $(p=0.011)$ and urea levels $(p<$ 0.001) (Table 3). Hospital stay did not differ between hypernatremia and normonatremia $(p=0.806)$. Thirtyday mortality was seen in $10(40 \%)$ and 1-year mortality in $15(60 \%)$ patients. Both short- and long-term mortality were significantly higher in hypernatremia.

Independent predictors for one-year mortality were higher $\mathrm{CCl}$ scores and the presence of hypernatremia (Table 4, Figure 3).

\section{DISCUSSION}

The present study indicates that when compared to normonatremia; hyponatremia correlates with higher leucocytes and lower albumin while hypernatremia correlates with female gender, higher leucocytes and urea levels. To the best of our knowledge, the current study presents a systematic comparison between hypernatremic and normonatremic hospitalized CAP patients for the first time. The study also revealed that hyponatremia prolongs hospital stay and increases long-term mortality. Hypernatremia, on the other hand, increases mortality both in the short- and longterm. Hypernatremia predicts long-term mortality better than hyponatremia.

Hyponatremia is more frequent in pneumonia compared to the overall hospitalizations in internal med- 


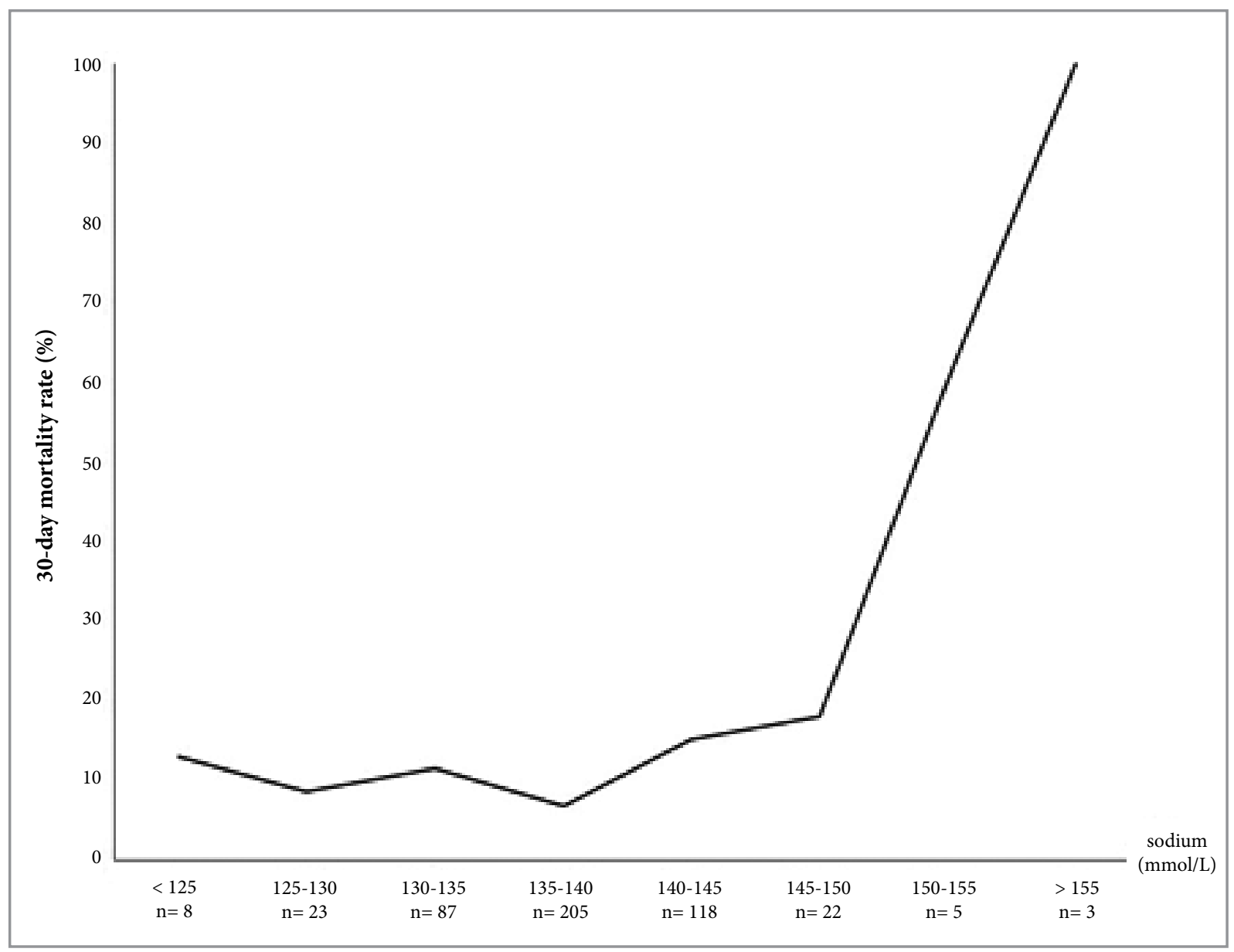

Figure 2. 30-day mortality risk according to categorical sodium values.

icine clinics. In general wards, the frequency of hyponatremia is reported as $12-15 \%(3,10,25)$. As for CAP, hyponatremia is described in $22-32 \%(4,12,17)$. The rate of hypernatremia differs according to the study unit. In neurologic ICU, baseline hypernatremia is reported as $13 \%$ (26). In patients with CAP, hypernatremia is determined in $1-3 \%(3,4,10,27)$. The present study has revealed a hyponatremia rate complies with, however a slightly higher hypernatremia rate. In most of the studies the sodium levels were not corrected based on glucose levels, which we believe, may be the reason of different findings. In line with this comment, Tsipotis et al. have put forward that after having corrected the baseline sodium levels a higher frequency of pneumonia and sepsis in hypernatremic patients have been reported (13). Furthermore, there may be a geographical and different microbiologic spectrum affecting the prevalence of dysnatremia. Novel research and studies may enlighten this issue.
Only few studies have analyzed the related parameters with hyponatremia. Older age and higher $\mathrm{CCl}$ scores have been referred to all-caused hyponatremia (10). In patients with CAP, leucocytes and CRP, older age and higher $\mathrm{CCl}$ scores were defined as correlative factors for hyponatremia $(11,12)$. A current study all pneumonia, demographics were found similar whereas hyponatremic patients had more frequent malignancy, renal failure, and legionella infection (19). In present study, demographics and CCl scores were similar. Leucocytes and lower albumin levels best correlated with hyponatremia.

Various studies have marked a worse survival in hyponatremic patients with various diseases heart failure, severe liver disease and cancer $(3,4,15$ $17,28,29)$. In liver disease and congestive heart failure, a U-shaped association between serum sodium level and mortality was emphasized $(15,16)$. In the multicentre study of Krüger et al., both inpatients and outpatients with CAP demonstrated a U-shaped asso- 
Table 3. Comparison of normonatremic patients with hypernatremics

\begin{tabular}{|c|c|c|c|}
\hline & $\begin{array}{c}\text { Normonatremia } \\
(135-145 \mathrm{mmol} / \mathrm{L}) \\
(\mathrm{n}=327)\end{array}$ & $\begin{array}{l}\text { Hypernatremia } \\
(>145 \mathrm{mmol} / \mathrm{L}) \\
(\mathrm{n}=25)\end{array}$ & $\mathbf{p}$ \\
\hline Male gender, n (\%) & $218(67)$ & $10(40)$ & 0.009 \\
\hline Age, years & $65 \pm 18$ & $74 \pm 13$ & 0.025 \\
\hline $\mathrm{CCl}$ score & $3.7 \pm 2.1$ & $4.4 \pm 1.7$ & 0.102 \\
\hline Leucocytes $(/ \mu \mathrm{L})$ & $12.7 \pm 6.5$ & $16.8 \pm 14.9$ & 0.011 \\
\hline Hemoglobin (g/dL) & $12 \pm 1.9$ & $11.9 \pm 2.1$ & 0.508 \\
\hline NLR & $10.7 \pm 21$ & $16.9 \pm 23$ & 0.255 \\
\hline Platelets $(/ \mu \mathrm{L})$ & $279 \pm 123$ & $264 \pm 100$ & 0.595 \\
\hline $\mathrm{CRP}(\mathrm{mg} / \mathrm{L})$ & $129 \pm 106$ & $176 \pm 88$ & 0.056 \\
\hline BUN (mg/dL) & $49.4 \pm 30$ & $84 \pm 52$ & $<0.001$ \\
\hline Albumin $(\mathrm{g} / \mathrm{dL})$ & $2.4 \pm 1.4$ & $2.6 \pm 0.9$ & 0.453 \\
\hline LOS (days) & $7.5 \pm 4.6$ & $7.7 \pm 6.2$ & 0.806 \\
\hline 30-day mortality, n (\%) & $32(10)$ & $10(40)$ & $<0.001$ \\
\hline 1-year mortality, n (\%) & $78(24)$ & $15(60)$ & 0.001 \\
\hline
\end{tabular}

Table 4. Cox regression analysis of one-year mortality

\begin{tabular}{|lcc|} 
& HR $(\mathbf{C l}$ 95\%) & p \\
\hline Gender & $0.972(0.653-1.446)$ & 0.888 \\
Age & $1.016(0.997-1.035)$ & 0.104 \\
CCl score & $1.275(1.126-1.144)$ & $<0.001$ \\
Leucocytes & $0.995(0.969-1.022)$ & 0.716 \\
Hypernatremia & $0.265(0.134-0.525)$ & $<0.001$ \\
Hyponatremia & $0.908(0.596-1.384)$ & 0.654 \\
\hline CCl: Charlson comorbidity index, HR: Hazard ratio. & & \\
\hline
\end{tabular}

ciation between serum sodium level and mortality. Serum sodium levels were not corrected in this study (12). A recent study by Müller et al. has defined similar ICU admission with higher in-hospital mortality in hyponatremic pneumonia (19). This study has included only patients with pneumonia admitted to emergency department. The cut-off value for hyponatremia was defined as $130 \mathrm{mmol} / \mathrm{L}$ and $7.7 \%$ of the patients had baseline hyponatremia. Also, all hospital-acquired and CAP patients were included and sodium levels were not recalculated. Contrary to these results, Zilberberg et al. did not find any relationship between in-hospital mortality and hyponatremia in patients with pneumonia (11). In line with this report, the present study did not reveal a relationship between one-month mortality and low sodium levels. In 2011, Chawla et al. analyzed the relationship between corrected hyponatremia and mortality in all-cause hospitalizations. A degree-related mortality with sodium levels was refused in the study and the authors concluded that decreased serum sodium reflects more severe underlying disease rather than causing the death itself (18). Similarly, in our study, $\mathrm{CCl}$ levels did not differ significantly between hypoand normo-natremics and we infer that such lack of varying may be the reason of similar short-term outcome of these patients.

\section{Hospital Stay and Long-Term Outcome of Hyponatremia}

Only a limited number of studies have focused on hospital stay and hyponatremia. A recent study 
reported no relationship between sodium levels and hospital stay (19). In contrast, other studies have proved longer LOS in hyponatremia $(4,17)$. Similar to these studies, duration of hospitalization is indicated to be longer in the current study. We think that, since the demographics and $\mathrm{CCl}$ scores are similar in these patients, longer LOS may be caused by higher baseline CRP levels as well as the treatment duration for correcting hyponatremia.

To our knowledge, only one study has investigated long-term outcome in hyponatremic CAP patients concluding higher long-term mortality with lower baseline sodium levels (4). In line with this study, we have found worse long-term survival in hyponatremic CAP patients.

Hypernatremia-related factors have been studied less frequently in the literature. Hypernatremic and normonatremic patients hospitalized in medical wards were investigated without a statistical comparison. The average age was higher and female gender $(53 \%$ vs. $47 \%$ ) was more frequent in hypernatremics. Co-morbidities were compared discretely and hypertension, congestive heart failure, renal failure and cerebrovascular disease were reported more frequent in hypernatremia (4). In all-cause hospitalizations, hospital-acquired hypernatremia is reported to be higher in advanced age, higher comorbidity index, lower estimated glomerular filtration rate (13). In septic ICU patients, acute physiology and chronic health evaluation II score is found to be associated with hypernatremia (14). The present study attests that hypernatremia is more frequent in females and advanced age. Higher baseline leucocytes and urea levels were found to be associated with hypernatremia. Due to the low number of hypernatremic patients, a logistic regression analysis was not performed. Further multi-centre studies may be required in this regard.

A uniform short- and long-term worse survival is reported in hypernatremia. In-hospital mortality is higher in hypernatremia in all-cause hospitalizations and pneumonia $(3,4,13)$. Ates et al. have revealed a $49.5 \%$ mortality in severe hypernatremic patients admitted to emergency department (30). The mortality risk is described higher in hypernatremia than in hyponatremia in various studies $(4,31)$. In present study, hypernatremic patients significantly less-survived than hypo- and normo-natremic patients. In parallel with the literature, long-term mortality is detected higher in hypernatremia in current study.
Hypernatremia and hospital acquired hypernatremia is found to increase hospital stay $(4,13)$. The present study, however, did not yield such a significance, which we believe is caused by early in-hospital death.

The first limitation of the present study is the retrospective, two-centre study design. The second is that the microbiological pathogens were not studied widely. On the other hand, the strength of the study is that the study benefits from the inclusion of a homogenous study group from two large chest disease clinics. Furthermore, the values of sodium were corrected and both short- and long- term prognoses were investigated.

In conclusion, hyponatremia causes longer hospital duration of treatment and hypernatremia represents a higher mortality risk than hyponatremia in hospitalised patients with CAP. Appropriate treatment should be given in dysnatremia with closer medical examination. Further prospective studies along with microbiologic spectrum of pneumonia may determine more secure cut-off levels for sodium.

\section{CONFLICT of INTEREST}

There is no conflict of interest related to this study.

\section{AUTHORSHIP CONTRIBUTIONS}

Concept/Design: FTA, MA, TS

Analysis/Interpretation: FTA, TS

Data Acquisition: FTA, AG

Writting: FTA

Critical Revision: FTA, MA, TS

Final Approval: All of authors.

\section{REFERENCES}

1. Xu J, Murphy SL, Kochanek KD, Bastian BA. Deaths: final data for 2013. Natl Vital Stat Rep 2016;64:1.

2. Pfuntner A, Wier LM, Stocks C. Most frequent conditions in U.S. hospitals, 2011. HCUP Statistical Brief \#162, Agency for Healthcare Research and Quality, Rockville, $M D$, September 2013.

3. Girardeau Y, Jannot AS, Chatellier G, Saint-Jean O. Association between borderline dysnatremia and mortality insight into a new data mining approach. BMC Med Inform Decis Mak 2017;17(1):152.

4. Akirov A, Diker-Cohen T, Steinmetz T, Amitai O, Shimon I. Sodium levels on admission are associated with mortality risk in hospitalized patients. Eur J Intern Med 2017;46:259. 
5. Anderson RI, Chung HM, Kluge R, Schrier RW. Hyponatremia: a prospective analysis of its epidemiology and the pathogenic role of vasopressin. Ann Intern Med 1985; 102:164e8.

6. Qian Q. Hypernatremia. Clin I Am Soc Nephrol 2019; 14(3):432-34.

7. Nagler EV, Vanmassenhove J, van der Veer SN, Nistor I, Van Biesen W, Webster AC, et al. Diagnosis and treatment of hyponatremia: a systematic review of clinical practice guidelines and consensus statements. BMC Med 2014;12:1.

8. Günaydin M, Gündüz A. Emergency management of the patient with altered mental status and coma. Turk Klin J Emerg Med 2017;3(3):201-6.

9. Kılınç $O$, Ece $T$, Arman D, et al. Türk Toraks Derneği erişkinlerde hastanede gelişen pnömoni tanı ve tedavi uzlaşı raporu. Turk Thorac J 2009; 10:3-24.

10. Holland-Bill L, Christiansen CF, Heide-Jorgensen $U$, Ulrichsen SP, Ring $T$, Jorgensen $J$, et al. Hyponatremia and mortality risk: a Danish cohort study of 279508 acutely hospitalized patients. Eur I Endocrinol 2015; 173(1):71-81.

11. Zilberberg MD, Exuzides A, Spalding J, Foreman A, Jones $A G$, Colby $C$, et al. Hyponatremia and hospital outcomes among patients with pneumonia: a retrospective cohort study. BMC Pulm Med 2008;8:16.

12. Krüger $S$, Ewig $S$, Giersdorf $S$, Hartmann $O$, Frechen $D$, Rohde G, et al. Dysnatremia, vasopressin, atrial natriuretic peptide and mortality in patients with communityacquired pneumonia: results from the german competence network CAPNETZ. Respir Med 2014;108(11):1696705.

13. Tsipotis E, Price $L L$, Jaber BL, Madias NE. Hospital associated hypernatremia spectrum and clinical outcomed in an unselected cohort. Am / Med 2018;131(1):72-82.

14. Ni HB, Hu XX, Huang XF, Liu KQ, Yu CB, Wang XM, et al. Risk factors and outcomes in patients with hypernatremia and sepsis. Am J Med Sci 2016;351(6):601-5.

15. Gheorghiade $M$, Abraham WT, Albert NM, Gattis Stough $W$, Greenberg BH, O'Connor CM, et al. Relationship between admission serum sodium concentration and clinical outcomes in patients hospitalized for heart failure: an analysis from the OPTIMIZE-HF registry. Eur Heart J 2007;28:980-8.

16. Kim WR, Biggins SW, Kremers WK, Wiesner RH, Kamath $P S$, Benson JT, et al. Hyponatremia and mortality among patients on the liver-transplant waiting list. N Engl I Med 2008;359:1018-26.

17. Nair V, Niederman MS, Masani N, Fishbane S. Hyponatremia in community acquired pneumonia. Am J Nephrol 2007;27:184-90.
18. Chawla A, Sterns RH, Nigwekar SU, Cappuccio JD. Mortality and serum sodium: do patients die from or with hyponatremia? Clin J Am Soc Nephrol 2011;6(5):960-5.

19. Müller M, Schefold IC, Guignard V, Exadaktylos AK, Pfortmueller CA. Hyponatremia is independently associated with in-hospital mortality in patients with pneumonia. Eur J Intern Med 2018;54:46-52.

20. Lindner G, Funk GC, Schwarz C, Kneidinger N, Kaider A, Schneeweiss B, et al. Hypernatremia in the critically ill is an independent risk factor for mortality. Am J Kidney Dis 2007; 50:95257.

21. Hoorn EJ, Betjes MGH, Weigel J, Zietse R. Hypernatremia in critically ill patients: too little water and too much salt. Nephrol Dial Transplant 2008;23:1562-8.

22. Stelfox $H T$, Ahmed SB, Khandwala F, Zygun D, Shahpori R, Laupland $K$. The epidemiology of intensive care unitacquired hyponatremia and hypernatremia in medicalsurgical intensive care units. Crit Care 2008;12(6):R162.

23. Sen S, Tran N, Chan B, Palmieri TL, Greenhalgh DG, Cho $K$. Sodium variability is associated with increased mortality in severe burn injury. Burns Trauma 2017;5:34.

24. Charlson ME, Pompei P, Ales KL, MacKenzie CR. A new method of classifying prognostic comorbidity in longitudinal studies: Development and validation. I Chron Dis 1987;40:373-83.

25. Uslu N, Sinangil A, Çelik $A V$, et al. Current approach to hyponatremia. FNG \& Bilim Tip Derg 2016;2(1):63-8.

26. Zhang $Y Z$, Qie $M Y$, Zhang $Q H$. Incidence and mortality prognosis of dysnatremias in neurologic critically ill patients. Eur Neurol 2015;73:29-36.

27. Arampatzis $S$, Frauchiger B, Fiedler GM, Leichtle AB, Buhl $D$, Schwarz C, et al. Characteristics, symptoms, and outcome of severe dysnatremias present on hospital admission. Am J Med 2012;125(11):1125.e1-1125.e7.

28. Doshi SM, Shah P, Lei X, Lahoti A, Salahudeen AK. Hyponatremia in hospitalized cancer patients and its impact on clinical outcomes. Am / Kidney Dis 2012;59(2):222-8

29. Jenq CC, Tsai MH, Tian YC, Chang MY, Lin CY, Lien JM, et al. Serum sodium predicts prognosis in critically ill cirrhotic patients. J Clin Gastroenterol 2010;44(39):220-6.

30. Ates I, Ozkayar N, Toprak G, Yılmaz N, Dede F. Factors associated with mortality in patients presenting to the emergency department with severe hypernatremia. Intern Emerg Med 2016;11(3):451-9.

31. Lindner G, Funk GC. Hypernatremia in critically ill patients. J Crit Care 2013;28(2):216.e11-20. 